\title{
Frequency of Common Variants in Genes Involved in Lipid-Lowering Response to Statins in Chilean Subjects with Hypercholesterolemia
}

\author{
Frecuencia de Polimorfismos en Genes Relacionados a la Respuesta Terapéutica \\ a Estatinas en Individuos Chilenos con Hipercolesterolemia
}

\author{
*Alexy Rosales; *Alejandro Pacheco; *Alejandro Cuevas; "Nicolás Saavedra; \\ "Tomás Zambrano; ${ }^{* *}$ Fernando Lanas \& "Luis A. Salazar
}

\begin{abstract}
ROSAleS, A.; PACHECO, A.; CUEVAS, A.; SAAVEDRA, N.; ZAMBRANO, T.; LANAS, F. \& SALAZAR, L. A. Frequency of common variants in genes involved in lipid-lowering response to statins in Chilean subjects with hypercholesterolemia. Int. J. Morphol., 29(4):1296-1302, 2011.
\end{abstract}

SUMMARY: Interindividual differences in activity and expression of the metabolizing enzymes cytochrome P450 (CYP) 3A4 and 3A5 and the multidrug efflux pump P-glycoprotein (P-gp, encoded by ABCB1 gene) contribute considerably to lipid-lowering efficacy of statin treatment in subjects with hypercholesterolemia. Variability in the activity of CYP3A4, CYP3A5 and P-gp could be considered to result from genetic polymorphisms encoding their genes. However, the available data indicate that the frequencies of ABCB1, CYP3A4 and CYP3A5 gene polymorphisms differ significantly across populations. Thus, the aim of the present study was to determine the allelic frequency of three common variants of these genes in Chilean individuals with primary hypercholesterolemia (HC) and controls. A total of 135 unrelated patients ( $44 \pm 7$ years old) with diagnosis of hypercholesterolemia (Total cholesterol $\geq 240 \mathrm{mg} / \mathrm{dL}$ ) and 120 normolipidemic healthy controls $(40 \pm 10$ years old; total cholesterol $\leq 200 \mathrm{mg} / \mathrm{dL}$ ) were included in this study. The $3435 \mathrm{C}>\mathrm{T}$ (MDR1), -290A > G (CYP3A4) and 6986A>G (CYP3A5) gene polymorphisms were analyzed by PCR-RFLP. The genotype distribution for 3435C>T variant of ABCB1 in HC patients (CC: 49\%, CT: 37\%, TT: 14\%) and controls (CC: 41\%, CT: 48\%, TT: 11\%) was comparable $(\mathrm{P}=0.186)$. Similarly, the genotype distribution for $-290 \mathrm{~A}>\mathrm{G}$ polymorphism of CYP3A4 in HC subjects $(\mathrm{AA}$ : $73 \%$, AG: 27\%, GG: 0\%) and controls (AA: 71\%, AG: 29\%, GG: 0\%) was equivalent ( $\mathrm{P}=0.863)$. Finally, the genotype distribution for 6986A>G variant of CYP3A5 in HC individuals (AA: 4\%, AG: 41\%, GG: 55\%) and controls (AA: 4\%, AG: 47\%, GG: 49\%) was similar (P=0.594). The allelic frequencies of 3435C $>\mathrm{T}$ (ABCB1), -290A $>\mathrm{G}$ (CYP3A4) and 6986A>G (CYP3A5) polymorphisms are similar between Chilean $\mathrm{HC}$ patients and controls, and comparable to frequencies found in Asian populations.

KEY WORDS: Polymorphisms; Statins; Hypercholesterolemia; ABCB1.

\section{INTRODUCTION}

There is abundant evidence that, for prevention and treatment of cardiovascular diseases (CVD), an important reduction in common risk factors must be achieved, promoting changes in lifestyle, which accompanied with specific pharmacological treatment of lipid disorders, can reduce in a significant manner a future cardiovascular event (Lanas et al., 2007; Medina \& Kaempffer, 2007).

Different types of drugs are co-administered to CVD patients, many of which have become a mainstay in the primary (Pignone et al., 2000) and secondary prevention
(Shepherd et al., 1995) of coronary events, reducing cardiovascular mortality and morbidity. However, the backbone of lipid lowering medication is accomplished mainly by 3-hydroxy-3-methyl-glutaryl-coenzyme A(HMGCo A) reductase inhibitors, or statins (Vaughan et al., 2000; Newman et al., 2003).

Statins are among the most used drugs worldwide. They are usually very well tolerated. Nevertheless, they can cause severe adverse reactions, such as myopathy and rhabdomyolysis, the risk of which is increased by certain

\footnotetext{
* Centro de Biología Molecular \& Farmacogenética, Departamento de Ciencias Básicas, Facultad de Medicina, Universidad de La Frontera, Temuco, Chile. **Departamento de Medicina Interna, Facultad de Medicina, Universidad de La Frontera, Temuco, Chile.

This study was supported by grants from DIUFRO Project (DI09-1007).
} 
interactions as a rare, plasma concentration-dependent adverse reaction (Niemi, 2010). Alternatively, the benefits of statins are very well documented. Experimental studies have recognized evidence of different positive effects such as an increment in the nitric oxide (NO) expression, antiinflammatory, immunomodulatory, anti-thrombotic, antiproliferative, and anti-oxidant effects (Echeverri et al., 2005; Kirmizis et al., 2009).

The mechanism of action of statins is to inhibit in a competitive and reversible way an enzyme named HMGCoA reductas, which catalyzes biosynthesis of hepatic cholesterol by blocking the formation of mevalonic acid and reducing intracellular cholesterol synthesis, resulting in a compensatory increase in expression of LDL receptors in liver cells, reducing LDL-C levels of circulating total cholesterol (20\% - 50\% approximately, respectively) subsequently increases the removal of triglyceride-rich lipoproteins from plasma and reduces synthesis of apoBcontaining lipoproteins, such as VLDL. It also give rise to a modest decrease in triglycerides (TG, $10 \%$ to $40 \%$ ) and a small increased levels of high density lipoprotein (HDL) cholesterol (5\% to 15\%) levels (Vaughan et al.; Marhuenda, 2002). Several studies have shown that with $1 \%$ reduction in LDL cholesterol level, there is an associated $1 \%$ reduction in risk of clinical cardiovascular events (LaRosa, 2007).

To date, there are more than 40 genes investigated that could affect clinical response to statins (Thompson $e t$ al., 2005), which are related to both, pharmacokinetics (metabolizing enzymes and transport proteins) and pharmacodynamics (receptors and signal transduction pathways) (Neuvonen et al., 2006). Some inter-individual drug effects are based on pathophysiological factors and environmental interactions, but also genetic characteristics. Large interindividual pharmacokinetic differences observed among humans are partially due to genetic polymorphisms in drug-metabolizing enzymes such as cytochrome P450, or transporter proteins such a ABCB1 (Evans et al., 2001). These variations include genes involved in intestinal absorption of cholesterol and apolipoprotein E (APOE), ATP transporter (ATP binding cassette) the production of cholesterol, including HMG-CoA reductase, the metabolism of lipoproteins and apolipoprotein B and LDL receptor, also including the cytochrome P450 (Salazar et al., 2000; Kajinami et al., 2005; Wang et al., 2005; Kerola et al., 2010).

Statins are metabolized in hepatic and intestinal tissue by the cytochrome P450-system (CYP450), mainly by CYP3A sub-family (CYP3A4 and CYP3A5 isoforms included). CYP3A plays an important role in human metabolism (Igel et al., 2001). On the other hand, simvastatin, lovastatin, and atorvastatin are metabolized by cytochrome P450 (CYP) 3A4 (Malinowski, 1998; Neuvonen et al.). In the case of atorvastatin, there are differences in the clinical response, which could be explained by genetic polymorphisms (Cascorbi et al., 2001). An example of this is the case of CYP3A sub-family, variations in genes involved in uptake, distribution, and metabolism of statins may also significantly modulate response. In the same way, Pglycoprotein, the gene product of ABCB1 (MDR1), is an integral membrane protein of $170 \mathrm{kd}$, belonging to the adenosine triphosphate-binding cassette superfamily of membrane transporters, conferring multidrug resistance and playing a fundamental role in the bioavailability (absorption, distribution and elimination) of common drugs used in medical care.

The level of protein expression and functional integrity of P-glycoprotein directly affects its pharmacokinetic interaction with therapeutically administered drugs and therefore plays an important role in efficacy and toxicity of drug treatment (Eichelbaum et al., 2004; Ieiri et al., 2004). ABCB1 transports a wide range of drugs, including atorvastatin (Dietrich et al., 2003). The latter undergoes hepatic metabolism mediated by phase I and phase II enzymes, or may be excreted without any further transformation. ABCB 1 is located in the canalicular membrane of hepatocytes, contributing to statin removal and their metabolites via bile (Lennernäs, 2003; Rodrigues et al., 2006). Genetic variants of MDR1 can naturally affect the pharmacokinetic and pharmacodynamic profile of many drugs, generating interindividual difference and accounting for a variation in bioavailability of various P-gp substrates.

Various studies have analyzed single nucleotide polymorphisms (SNPs) in candidate genes as an approach for understanding partially the subjacent reason of drug response variability. This includes genes relevant to metabolizing enzymes such a CYP3A4 and CYP3A5 gene (Lee et al., 2002), transport protein MDR1 (ABCB1) gene (Ayrton \& Morgan, 2001), cholesterol biosynthesis (HMGCR). In these studies, different common variants were identified -260A $>\mathrm{G}$ (CYP3A4) (Kajinami et al., 2004a), 6986A $>\mathrm{G}$ (CYP3A5) (Kim et al., 2007) and 3435C $>\mathrm{T}$ (ABCB1 or MDR1) (Rodrigues et al., 2005) which were associated to a possible response variation and with efficacy of lipid-lowering therapy. CYP3A5*3 allele, was found to cause alternative splicing and protein truncation, resulting in the absence of functional CYP3A5 from liver tissue (Kuehl et al., 2001).

Futhermore, SNPs are considered to be a genetic contributor to inter-individual differences in response to statin therapy. Nevertheless, polymorphisms in drug 
metabolizing enzymes and transporters and their relationship to efficacy and adverse effects of statin therapy necessitate further research. Thus, the objective of this study was to determine the allelic frequency of three common genetic variants related to lipid-lowering response to statins in Chilean individuals with hypercholesterolemia and controls.

\section{MATERIAL AND METHOD}

Subjects. We analyzed 135 unrelated individuals with diagnosis of primary hypercholesterolemia (Total cholesterol $\geq 240 \mathrm{mg} / \mathrm{dL}$ ) and 120 normolipidemic controls (Total cholesterol $\leq 200 \mathrm{mg} / \mathrm{dL}$ ), in according to Expert Panel on Detection, Evaluation, and Treatment of High Blood Cholesterol in Adults (2001) criteria, selected from Hernán Henríquez Aravena Hospital (Temuco, Chile). None of the subjects had diabetes, hepatic disease, kidney disease, endocrinological disorders, malignant disease or was receiving concomitant lipid-lowering therapy. Patients with clinical diagnosis of familial hypercholesterolemia $(\mathrm{FH})$ were also excluded. The study protocol was approved by the Ethics Committee of Universidad de La Frontera and all participants included voluntarily signed an informed consent.

Blood samples were obtained after 12 hours fast. Biochemical measurements were determined by enzymatic methods previously described (Jaramillo et al., 2006) and low-density lipoprotein cholesterol was calculated by Friedewald formula, when plasma triglycerides did not exceed $400 \mathrm{mg} / \mathrm{dL}$. The accuracy of biochemical determinations was controlled using normal and pathological commercial serums (Human, Germany).

Molecular analysis. Genomic DNA was extracted from blood leukocytes using a method previously described (Salazar et al., 1998). The integrity of the genomic DNA was evaluated by electrophoresis in a $1.5 \%$ agarose gel. The 3535C > T (ABCB1), -290A $>\mathrm{G}$ (CYP3A4) and 6986A $>\mathrm{G}$ (CYP3A5) gene polymorphisms were detected using polymerase chain reaction followed by restriction fragment length polymorphism (PCR-RFLP) in according to conditions previously described (Cavalli et al., 2001; Rodrigues et al., 2005; Kim et al.). As positive control a homozygous sample for each variant was included. In addition, all gels were reread blindly by two persons and $20 \%$ of the analyses were randomly repeated. The digestion fragments were separated by electrophoresis (3.0\% agarose gel), stained with ethidium bromide and visualized on a UV transilluminator.
Statistical analysis. The collected data was analyzed using the SigmaStat software, version 2.0 (Jandel Sci., San Rafael, CA, USA). The association between the different analyzed variables was verified by Student $t$ test. For comparison of proportions and to evaluate the achievement of the Hardy-Weinberg equilibrium Chi-square test $\left(\mathrm{c}^{2}\right)$ was used. Statistical significance was considered as $\mathrm{P}<$ 0.05 .

\section{RESULTS}

Clinical variables. Table I summarizes the anthropometric, clinical and laboratory characteristics of 255 Chilean individuals enrolled in the study. The serum lipids concentrations (mean $\pm \mathrm{SD}$ ) of hypercholesterolemic (HC) subjects and controls are also presented. The baseline total cholesterol, LDL-cholesterol and triglycerides were higher in patients with $\mathrm{HC}(\mathrm{p}<0.001)$. The individuals belonging to control group showed higher HDL-cholesterol levels $(p<0.001)$ than HC group. No differences were achieved in the mean value of diastolic $(\mathrm{p}=0.066)$ and systolic $(\mathrm{p}=0.049)$ blood pressures between the studied groups.

Allelic frequencies. The genotype distribution and relative allele frequencies for the $3435 \mathrm{C}>\mathrm{T}(\mathrm{ABCB} 1),-290 \mathrm{~A}>\mathrm{G}$ (CYP3A4), and 6986A>G (CYP3A5) gene polymorphisms are shown in Table II. In both groups, the observed genotype distribution was consistent with Hardy-Weinberg equilibrium (Hypercholesterolemic subjects: $\mathrm{c} 2=3.33, \mathrm{c}^{2}$ $=2.40$ and $\mathrm{c} 2=1.76$ and controls: $\mathrm{c}^{2}=0.46, \mathrm{c}^{2}=3.49$ and $c^{2}=3.48$, for $3435 \mathrm{C}>\mathrm{T},-290 \mathrm{~A}>\mathrm{G}$ and $6986 \mathrm{~A}>\mathrm{G}$ polymorphisms, respectively). The genotype distribution for $3435 \mathrm{C}>\mathrm{T}$ variant of $\mathrm{ABCB} 1$ gene in $\mathrm{HC}$ patients $(\mathrm{CC}$ : 49\%, CT: $37 \%$, TT: $14 \%$ ) and controls (CC: 41\%, CT: $48 \%$, TT: $11 \%)$ was comparable $(\mathrm{p}=0.186)$. The mutated allele (3435T) in control and $\mathrm{HC}$ subjects was also similar ( 0.35 vs. $0.33, \mathrm{p}=0.631$ ).

Similarly, the genotype distribution for $-290 \mathrm{~A}>\mathrm{G}$ polymorphism of CYP3A4 gene in HC subjects (AA: 73\%, AG: $27 \%$, GG: $0 \%$ ) and controls (AA: $71 \%$, AG: $29 \%$, GG: $0 \%$ ) was equivalent ( $\mathrm{p}=0.863$ ). The $\mathrm{GG}$ homozygous genotype was not observed in our study. The allelic frequency of mutated allele variant (-290G) in HC and control subjects was also comparable. Finally, the genotype for $6986 \mathrm{~A}>\mathrm{G}$ variant of CYP3A5 in HC individuals (AA: 4\%, AG: 41\%, GG: 55\%) and controls (AA: 4\%, AG: 47\%, GG: $49 \%)$ was similar $(\mathrm{p}=0.594)$. The frequency for the wild-type $(\mathrm{CYP} 3 \mathrm{~A} 5 * 1)$ and variant $(\mathrm{CYP} 3 \mathrm{~A} 5 * 3)$ alleles were 0.27 and 0.73 for control subjects and 0.24 and 0.76 for $\mathrm{HC}$ individuals. 
Table I. Clinical characteristics of Chilean subjects with hypercholesterolemia (HC) and controls.

\begin{tabular}{lccc}
\hline & HC $(\mathbf{n = 1 3 5})$ & Controls $(\mathbf{n = 1 2 0})$ & $\mathbf{P} *$ \\
\hline Age, years & $44 \pm 7$ & $40 \pm 10$ & 0.161 \\
Male, \% & 60 & 56 & 0.598 \\
BMI, Kg/m_ & $27.6 \pm 4,9$ & $25.5 \pm 3.3$ & $<0.001$ \\
SBP, mmHg & $118 \pm 10$ & $110 \pm 11$ & 0.049 \\
DBP, mmHg & $76 \pm 10$ & $70 \pm 10$ & 0.066 \\
Total cholesterol, mg/dL & $267 \pm 25$ & $163 \pm 23$ & $<0.001$ \\
LDL-C, mg/dL & $185 \pm 23$ & $94 \pm 24$ & $<0.001$ \\
HDL-C, mg/dL & $39 \pm 10$ & $50 \pm 12$ & $<0.001$ \\
Triglycerides, mg/dL & $192 \pm 64$ & $98 \pm 45$ & $<0.001$ \\
\hline
\end{tabular}

Results are expressed as mean \pm SD. BMI, body mass index; SBP, systolic blood pressure; DBP, diastolic blood pressure; LDL-C, low density lipoprotein-cholesterol; HDL-C, high density lipoprotein-cholesterol. *Student's t-test.

Table II. Genotype distribution and relative allele frequencies for 3435C>T (ABCB1), -290A>G (CYP3A4) and 6986A>G (CYP3A5) polymorphisms in Chilean individuals with hypercolesterolemia (HC) and controls.

\begin{tabular}{|c|c|c|c|c|c|c|}
\hline \multirow[t]{2}{*}{ Polymorphism } & \multirow[t]{2}{*}{ Group } & \multicolumn{3}{|c|}{ Genotypes (\%) } & \multicolumn{2}{|c|}{ Alleles } \\
\hline & & $\mathrm{CC}$ & $\mathrm{CT}$ & TT & $\mathrm{C}$ & $\mathrm{T}$ \\
\hline \multirow{3}{*}{$3435 \mathrm{C}>\mathrm{T}(\mathrm{ABCB} 1)$} & $\mathrm{HC}$ & $49(66)$ & $37(50)$ & $14(19)$ & 0.67 & 0.33 \\
\hline & Controls & $41(49)$ & $48(58)$ & $11(13)$ & 0.65 & 0.35 \\
\hline & & \multicolumn{3}{|c|}{$\chi^{2}=3.36 ;$ d.f. $=2 ; p=0.186$} & \multicolumn{2}{|c|}{$\chi^{2}=0.23 ;$ d.f. $=1 ; p=0.631$} \\
\hline \multirow{4}{*}{$-290 \mathrm{~A}>\mathrm{G} \quad$ (CYP3A4) } & & AA & $\mathrm{AG}$ & GG & A & G \\
\hline & $\mathrm{HC}$ & $73(98)$ & $27(37)$ & $0(0)$ & 0.86 & 0.14 \\
\hline & Controls & $71(85)$ & $29(35)$ & $0(0)$ & 0.85 & 0.15 \\
\hline & & \multicolumn{3}{|c|}{$\chi^{2}=0.29 ;$ d.f. $=1 ; p=0.863$} & \multicolumn{2}{|c|}{$\chi^{2}=0.24 ;$ d.f. $=1 ; p=0.875$} \\
\hline \multirow{4}{*}{6986 A>G (CYP3A5) } & & AA & $\mathrm{AG}$ & GG & $\mathrm{A}$ & G \\
\hline & $\mathrm{HC}$ & $4(5)$ & $41(55)$ & $55(75)$ & 0.24 & 0.76 \\
\hline & Controls & $4(5)$ & $47(56)$ & $49(59)$ & 0.27 & 0.73 \\
\hline & & \multicolumn{3}{|c|}{$\chi^{2}=1.04 ;$ d.f. $=2 ; p=0.594$} & \multicolumn{2}{|c|}{$\chi^{2}=0.61 ;$ d.f. $=1 ; p=0.434$} \\
\hline
\end{tabular}

Number of subjects in parenthesis; d.f., degree of freedom

\section{DISCUSSION}

There is a large interest in the connection between lipidlowering drug response and the relationship with genetic variants. Therefore, many investigations have been focusing on SNPs identification, and recognition of polymorphism frequency associated with lipid-lowering response in our populations has gained much importance. Given this scenery, the aim of the present study was to determine the frequency of three common variants in genes involved in statin response in Chilean $\mathrm{HC}$ individuals.

Our data shows that the frequency of the $\mathrm{G}$ allele was 0.35 in control subjects and 0.33 in $\mathrm{HC}$ for $3435 \mathrm{C}>\mathrm{T}$ polymorphism in the studied subjects. The results are similar to the frequencies observed by Wielandt et al. (2004) in Mapuche and Mestizo ethnicities of our country, having allelic frequencies of 0.35 and 0.33 , respectively. Similarly, in Brazilian hypercholesterolemic subjects, the frequency was 0.47 for $\mathrm{T}$ allele (Rodrigues et al., 2005). In addition, the frequency found in our study, for the $\mathrm{T}$ allele of the variant $3435 \mathrm{C}>\mathrm{T}$ is similar to that observed in Asian population such as Koreans (0.37) (Yi et al., 2004), higher in Rapanui populations (0.75) (Wielandt et al.), and differs significantly from that observed in Afro-Americans (0.21) (Kajinami et al., 2004b), Africans (0.17), European Caucasian (0.52) (Ameyaw et al., 2001) and Oceania population (0.53) (Roberts et al., 2002).

As for the polymorphism $-290 \mathrm{~A}>\mathrm{G}$ of CYP3A4 gene, the $\mathrm{G}$ allele was found in $15 \%$ of control and $14 \%$ of $\mathrm{HC}$ 
individuals studied. There are no previous reports of this polymorphism in our population, thus, this becoming the first study of variants of CYP3A4 in Chilean population. Comparing the frequency of the G allele (0.15) with those reported by other studies, we see a similarity with Brazilian population (0.13) (Cavalli et al.), Asian (0.16) (Thompson et al.) and Hispanic (0.09) (Ball et al., 1999), and the frequency of the mutant variant CYP3A4*1B was significantly higher than that observed in Europeans (0.05) (Sata et al., 2000) and American population, both white (0.04) and Black (0.54) (Ball et al.) and lower in Africans (0.82) (Zanger et al., 2008) and Afro-American (0.67) (Sata et al.). Gao et al. (2008) demonstrated an association between the presence of $\mathrm{G}$ allele in hypercholesterolemic individuals who had a greater reduction of total cholesterol levels, when treated with atorvastatin $20 \mathrm{mg} /$ day for 4 weeks in Asiatic population. Other investigators associated the presence of this variant (allele $\mathrm{G}$ ) to higher levels of LDL cholesterol after treatment, in $340 \mathrm{HC}$ individuals undergoing atorvastatin treatment $10 \mathrm{mg} / \mathrm{day}$ (Kajinami et al., 2004a).

In relation to the genetic polymorphism $6986 \mathrm{~A}>\mathrm{G}$, the $\mathrm{G}$ allele frequency was 0.73 in control subjects and 0.76 in hypercholesterolemic subjects. The results are very similar to the respective frequencies observed in some Asian populations such as Chinese (Hu et al., 2005) and Japanese (Horinouchi et al., 2002) for this variant, 0.77 and 0.76, respectively, different from the reported in American population (0.93) (Mega et al., 2009), Africans (0.15) (Kudzi et al., 2010), European Caucasians (0.93) (Dally et al., 2004) and very different in Afro-American population (0.36) (Kajinami et al., 2004b).

It has been well known that interindividual differences in the metabolic profile of many drugs are mainly due to sequence variants in gene encoding drug metabolizing enzymes. Therefore, knowledge of the prevalence of SNPs in a population is essential for the estimatation of the likelihood of interindividual differences of drug efficacy and other side effects. The influence of ethnicity on pharmacogenetic response must be taken into account by performing and comparing clinical trials in various ethnic groups.

Pharmacogenetic testing increases the impact on the individualization of drug treatment and could therefore contribute significantly to enhanced drug safety and efficacy (Pfost et al., 2000). In the near future, pharmacogenomics may allow the identification of patient subgroups which most likely profit from lipid-lowering therapy.

In summary, our study shows that the allelic frequencies of 3435C > T (ABCB1), $-290 \mathrm{~A}>\mathrm{G}(\mathrm{CYP} 3 \mathrm{~A} 4)$ and $6986 \mathrm{~A}>\mathrm{G}$ (CYP3A5) polymorphisms are similar between Chilean HC patients and controls, and comparable to frequencies described in Asian populations. However, the influence of these genetic variants on lipid-lowering response to statins in our population needs to be investigated in a further study.

ROSAleS, A.; PACHECO, A.; CUEVAS, A.; SAAVEDRA, N.; ZAMBRANO, T.; LANAS, F. \& SALAZAR, L. A. Frecuencia de polimorfismos en genes relacionados a la respuesta terapéutica a estatinas en individuos chilenos con hipercolesterolemia. Int. J. Morphol., 29(4):1296-1302, 2011.

RESUMEN: Polimorfismos de los genes CYP3A4, CYP3A5 y $\mathrm{ABCB} 1$ se han asociado a variaciones en la respuesta a fármacos hipolipemiantes, como las estatinas; principales medicamentos utilizados para disminuir los niveles plasmáticos de colesterol (CT). Sin embargo, la frecuencia de estas variantes genéticas puede variar entre las poblaciones. Así, el objetivo de este trabajo fue evaluar la frecuencia de tres polimorfismos de los genes CYP3A4, CYP3A5 y ABCB1, relacionados previamente a la respuesta a estatinas, en individuos chilenos hipercolesterolémicos (HC) y controles. Se analizaron 135 sujetos con diagnóstico de hipercolesterolemia primaria (CT $\geq 240 \mathrm{mg} / \mathrm{dL}$ ) y 120 controles (CT $\leq 200 \mathrm{mg} / \mathrm{dL}$ ) pertenecientes a la Región de La Araucanía (Chile). La genotipificación de las variantes genéticas se efectuó mediante la técnica de reacción en cadena de la polimerasa seguido de restricción enzimática (PCR-RFLP). La distribución de genotipos para la variante $3435 \mathrm{C}>\mathrm{T}$ del gen $\mathrm{ABCB} 1$ en los individuos $\mathrm{HC}$ (CC: $49 \%$, CT: $37 \%$, TT: $14 \%$ ) y controles (CC: $41 \%$, CT: $48 \%$, TT: $11 \%$ ) fue semejante $(\mathrm{P}=0,186)$. De forma similar, la distribución de genotipos para el polimorfismo $-290 \mathrm{~A}>\mathrm{G}$ del gen CYP3A4 en los pacientes $\mathrm{HC}$ (AA: $73 \%$, AG: $27 \%$, GG: $0 \%$ ) y controles (AA: $71 \%$, AG: $29 \%$, GG: $0 \%)$ fue equivalente $(\mathrm{P}=0,863)$. Del mismo modo, la distribución de genotipos para la variante $6986 \mathrm{~A}>\mathrm{G}$ del gen CYP3A5 en el grupo $\mathrm{HC}$ (AA: $4 \%$, AG: $41 \%$, GG: $55 \%$ ) y grupo control (AA: $4 \%$, AG: $47 \%$, GG: $49 \%)$ fue similar $(\mathrm{P}=0,594)$. En resumen, nuestro estudio demuestra que las frecuencias de los polimorfismos $3435 \mathrm{C}>\mathrm{T}$ (ABCB1), $290 \mathrm{~A}>\mathrm{G}(\mathrm{CYP} 3 \mathrm{~A} 4)$ y $6986 \mathrm{~A}>\mathrm{G}(\mathrm{CYP} 3 \mathrm{~A} 5)$ no difieren entre individuos $\mathrm{HC}$ y controles, y son comparables a las frecuencias encontradas en poblaciones asiáticas. Su efecto sobre el tratamiento con estatinas en la población chilena debe ser investigado.

PALABRAS CLAVE: Polimorfismos; Estatinas; Hipercolesterolemia; ABCB1.

\section{REFERENCES}

Ameyaw, M. M.; Regateiro, F.; Li, T.; Liu, X.; Tariq, M.; Mobarek, A.; Thornton, N.; Folayan, G. O.; Githang'a, J.; Indalo, A.; OforiAdjei, D.; Price-Evans, D. A. \& McLeod, H. L. MDR1 pharmacogenetics: frequency of the C3435T mutation in exon 26 is significantly influenced by ethnicity. Pharmacogenetics, 11(3):217-21, 2001.

Ayrton, A. \& Morgan, P. Role of transport proteins in drug absorption, distribution and excretion. Xenobiotica, 31(8-9):469-97, 2001.

Ball, S. E.; Scatina, J.; Kao, J.; Ferron, G. M.; Fruncillo, R.; Mayer, P.; Weinryb, I.; Guida, M.; Hopkins, P. J.; Warner, N. \& Hall, J. Population distribution and effects on drug metabolism of a genetic variant in the 5' promoter region of CYP3A4. Clin. Pharmacol. Ther., 66(3):288-94, 1999. 
Cascorbi, I.; Gerloff, T.; Johne, A.; Meisel, C.; Hoffmeyer, S.; Schwab, M.; Schaeffeler, E.; Eichelbaum, M.; Brinkmann, U. \& Roots, I. Frequency of single nucleotide polymorphisms in the Pglycoprotein drug transporter MDR1 gene in white subjects. Clin. Pharmacol. Ther., 69(3):169-74, 2001.

Cavalli, S. A.; Hirata, M. H. \& Hirata, R. D. Detection of MboII polymorphism at the 5' promoter region of CYP3A4. Clin. Chem., 47(2):348-51, 2001.

Dally, H.; Bartsch, H.; Jager, B.; Edler, L.; Schmezer, P.; Spiegelhalder, B.; Dienemann, H.; Drings, P.; Kayser, K.; Schulz, V. \& Risch, A. Genotype relationships in the CYP3A locus in Caucasians. Cancer Lett., 207(1):95-9, 2004.

Dietrich, C. G.; Geier, A. \& Oude Elferink, R. P. ABC of oral bioavailability: transporters as gatekeepers in the gut. Gut, 52(12):1788-95, 2003.

Echeverri, D.; Buitrago, L. \& Montes, F. Efectos pleiotrópicos de las estatinas. Características farmacológicas útiles en la prevención, tratamiento y regresión de la enfermedad cardiovascular. Rev. Colomb. Cardiol., 12(3):103-12, 2005.

Eichelbaum, M.; Fromm, M. F. \& Schwab, M. Clinical aspects of the MDR1 (ABCB1) gene polymorphism. Ther. Drug Monit., 26(2):180-5, 2004.

Evans, W. E. \& Johnson, J. A. Pharmacogenomics: the inherited basis for interindividual differences in drug response. Annu. Rev. Genomics Hum. Genet., 2:9-39, 2001.

Expert Panel on Detection, Evaluation, and Treatment of High Blood Cholesterol in Adults. Executive Summary of The Third Report of The National Cholesterol Education Program (NCEP) Expert Panel on Detection, Evaluation, And Treatment of High Blood Cholesterol In Adults (Adult Treatment Panel III). JAMA, 285(19):2486-97, 2001.

Gao, Y.; Zhang, L. R. \& Fu, Q. CYP3A4*1G polymorphism is associated with lipid-lowering efficacy of atorvastatin but not of simvastatin. Eur. J. Clin. Pharmacol., 64(9):877-82, 2008.

Horinouchi, M.; Sakaeda, T.; Nakamura, T.; Morita, Y.; Tamura, T.; Aoyama, N.; Kasuga, M. \& Okumura, K. Significant genetic linkage of MDR1 polymorphisms at positions 3435 and 2677: functional relevance to pharmacokinetics of digoxin. Pharm. Res., 19(10):1581-5, 2002.

Hu, Y. F.; He, J.; Chen, G. L.; Wang, D.; Liu, Z. Q.; Zhang, C.; Duan, L. F. \& Zhou, H. H. CYP3A5*3 and CYP3A4*18 single nucleotide polymorphisms in a Chinese population. Clin. Chim. Acta, 353(12):187-92, 2005.

Ieiri, I.; Takane, H. \& Otsubo, K. The MDR1 (ABCB1) gene polymorphism and its clinical implications. Clin. Pharmacokinet., 43(9):553-76, 2004.

Igel, M.; Sudhop, T. \& von Bergmann, K. Metabolism and drug interactions of 3-hydroxy-3-methylglutaryl coenzyme A-reductase inhibitors (statins). Eur. J. Clin. Pharmacol., 57(5):357-64, 2001.

Jaramillo, P. C.; Muñoz, M. A.; Lanas, M. C.; Lanas, Z. F. \& Salazar, L. A. Endothelial nitric oxide synthase G894T gene polymorphism in Chilean subjects with coronary artery disease and controls. Clin. Chim. Acta, 371(1-2):102-6, 2006.

Kajinami, K.; Akao, H.; Polisecki, E. \& Schaefer, E. J. Pharmacogenomics of statin responsiveness. Am. J. Cardiol., 96(9A):65K-70K; discussion 34K-35K, 2005.

Kajinami, K.; Brousseau, M. E.; Ordovas, J. M. \& Schaefer, E. J. CYP3A4 genotypes and plasma lipoprotein levels before and after treatment with atorvastatin in primary hypercholesterolemia. Am. J. Cardiol., 93(1):104-7, 2004a.

Kajinami, K.; Brousseau, M. E.; Ordovas, J. M. \& Schaefer, E. J. Polymorphisms in the multidrug resistance-1 (MDR1) gene influence the response to atorvastatin treatment in a gender-specific manner. Am. J. Cardiol., 93(8):1046-50, 2004b.

Kerola, T.; Lehtimäki, T.; Kähönen, M. \& Nieminen, T. Statin Pharmacogenomics: Lipid Response and Cardiovascular Outcomes. Curr. Cardio. Risk Rep., 4(2):150-8, 2010.

Kim, K. A.; Park, P. W.; Lee, O. J.; Kang, D. K. \& Park, J. Y. Effect of polymorphic CYP3A5 genotype on the single-dose simvastatin pharmacokinetics in healthy subjects. J. Clin. Pharmacol., 47(1):87-93, 2007.

Kirmizis, D. \& Chatzidimitriou, D. Pleiotropic vasoprotective effects of statins: the chicken or the egg? Drug Des. Devel. Ther., 3:191204, 2009.

Kudzi, W.; Dodoo, A. N. \& Mills, J. J. Genetic polymorphisms in MDR1, CYP3A4 and CYP3A5 genes in a Ghanaian population: a plausible explanation for altered metabolism of ivermectin in humans? BMC Med. Genet., 11:111, 2010.

Kuehl, P.; Zhang, J.; Lin, Y.; Lamba, J.; Assem, M.; Schuetz, J.; Watkins, P. B.; Daly, A.; Wrighton, S. A.; Hall, S. D.; Maurel, P.; Relling, M.; Brimer, C.; Yasuda, K.; Venkataramanan, R.; Strom, S.; Thummel, K.; Boguski, M. \& Schuetz, E. Sequence diversity in CYP3A promoters and characterization of the genetic basis of polymorphic CYP3A5 expression. Nat. Genet., 27(4):383-91, 2001.

Lanas, F.; Avezum, A.; Bautista, L. E.; Diaz, R.; Luna, M.; Islam, S.; Yusuf, S. \& INTERHEART Investigators in Latin America. Risk factors for acute myocardial infarction in Latin America: the INTERHEART Latin American study. Circulation, 115(9):106774, 2007.

LaRosa, J. C. Low-density lipoprotein cholesterol reduction: the end is more important than the means. Am. J. Cardiol., 100(2):240-2, 2007.

Lee, C. R.; Goldstein, J. A. \& Pieper, J. A. Cytochrome P450 2C9 polymorphisms: a comprehensive review of the in-vitro and human data. Pharmacogenetics, 12(3):251-63, 2002. 
Lennernäs, H. Clinical pharmacokinetics of atorvastatin. Clin. Pharmacokinet., 42(13):1141-60, 2003.

Malinowski, J. M. Atorvastatin: a hydroxymethylglutaryl-coenzyme A reductase inhibitor. Am. J. Health Syst. Pharm., 55(21):22532267; quiz 2302-3, 1998.

Marhuenda, E. Estatinas en el tratamiento de dislipidemias. Ars. Pharmaceutica, 43(1-2):83-5, 2002.

Medina, E. \& Kaempffer, A. Epidemiology of cardiovascular disease in Chile. Rev. Chil. Cardiol., 26:219-26, 2007.

Mega, J. L.; Morrow, D. A.; Brown, A.; Cannon, C. P. \& Sabatine, M. S. Identification of genetic variants associated with response to statin therapy. Arterioscler. Thromb. Vasc. Biol., 29(9):1310-5, 2009.

Neuvonen, P. J.; Niemi, M. \& Backman, J. T. Drug interactions with lipid-lowering drugs: mechanisms and clinical relevance. Clin. Pharmacol. Ther., 80(6):565-81, 2006.

Newman, C. B.; Palmer, G.; Silbershatz, H. \& Szarek, M. Safety of atorvastatin derived from analysis of 44 completed trials in 9,416 patients. Am. J. Cardiol., 92(6):670-6, 2003.

Niemi, M. Transporter pharmacogenetics and statin toxicity. Clin. Pharmacol. Ther., 87(1):130-3, 2010.

Pfost, D. R.; Boyce-Jacino, M. T. \& Grant, D. M. A SNPshot: pharmacogenetics and the future of drug therapy. Trends Biotechnol., 18(8):334-8, 2000.

Pignone, M.; Phillips, C. \& Mulrow, C. Use of lipid lowering drugs for primary prevention of coronary heart disease: meta-analysis of randomised trials. BMJ, 321(7267):983-6, 2000.

Roberts, R. L.; Joyce, P. R.; Mulder, R. T.; Begg, E. J. \& Kennedy, M. A. A common P-glycoprotein polymorphism is associated with nortriptyline-induced postural hypotension in patients treated for major depression. Pharmacogenomics J., 2(3):191-6, 2002.

Rodrigues, A. C.; Curi, R.; Britto, L. R.; Rebbechi, I. M.; Hirata, M. H.; Bertolami, M. C.; Bernik, M. M.; Dorea, E. L. \& Hirata, R. D. Down-regulation of $\mathrm{ABCB} 1$ transporter by atorvastatin in a human hepatoma cell line and in human peripheral blood mononuclear cells. Biochim. Biophys. Acta, 1760(12):1866-73, 2006.

Rodrigues, A. C.; Rebecchi, I. M.; Bertolami, M. C.; Faludi, A. A.; Hirata, M. H. \& Hirata, R. D. High baseline serum total and LDL cholesterol levels are associated with MDR1 haplotypes in Brazilian hypercholesterolemic individuals of European descent. Braz. J. Med. Biol. Res., 38(9):1389-97, 2005.

Salazar, L. A.; Hirata, M. H.; Cavalli, S. A.; Machado, M. O. \& Hirata, R. D. Optimized procedure for DNA isolation from fresh and cryopreserved clotted human blood useful in clinical molecular testing. Clin. Chem., 44(8 Pt 1):1748-50, 1998.

Salazar, L. A.; Hirata, M. H.; Quintão, E. C. \& Hirata, R. D. Lipid- lowering response of the HMG-CoA reductase inhibitor fluvastatin is influenced by polymorphisms in the low-density lipoprotein receptor gene in Brazilian patients with primary hypercholesterolemia. J. Clin. Lab. Anal., 14(3):125-31, 2000.

Sata, F.; Sapone, A.; Elizondo, G.; Stocker, P.; Miller, V. P.; Zheng, W.; Raunio, H.; Crespi, C. L. \& Gonzalez, F. J. CYP3A4 allelic variants with amino acid substitutions in exons 7 and 12: evidence for an allelic variant with altered catalytic activity. Clin. Pharmacol. Ther., 67(1):48-56, 2000.

Shepherd, J.; Cobbe, S. M.; Ford, I.; Isles, C. G.; Lorimer, A. R.; MacFarlane, P. W.; McKillop, J. H. \& Packard, C. J. Prevention of coronary heart disease with pravastatin in men with hypercholesterolemia. West of Scotland Coronary Prevention Study Group. N. Engl. J. Med., 333(20):1301-7, 1995.

Thompson, J. F.; Man, M.; Johnson, K. J.; Wood, L. S.; Lira, M. E.; Lloyd, D. B.; Banerjee, P.; Milos, P. M.; Myrand, S. P.; Paulauskis, J.; Milad, M. A. \& Sasiela, W. J. An association study of 43 SNPs in 16 candidate genes with atorvastatin response. Pharmacogenomics J., 5(6):352-8, 2005.

Vaughan, C. J.; Gotto, A. M. Jr. \& Basson, C. T. The evolving role of statins in the management of atherosclerosis. J. Am. Coll. Cardiol., 35(1):1-10, 2000.

Wang, A.; Yu, B. N.; Luo, C. H.; Tan, Z. R.; Zhou, G.; Wang, L. S.; Zhang, W.; Li, Z.; Liu, J. \& Zhou, H. H. Ile118Val genetic polymorphism of CYP3A4 and its effects on lipid-lowering efficacy of simvastatin in Chinese hyperlipidemic patients. Eur. J. Clin. Pharmacol., 60(12):843-8, 2005.

Wielandt, A. M.; Vollrath, V. \& Chianale, J. Polymorphisms of the multiple drug resistance gene (MDR1) in Mapuche, Mestizo and Maori populations in Chile. Rev. Med. Chil., 132(9):1061-8, 2004.

Yi, S. Y.; Hong, K. S.; Lim, H. S.; Chung, J. Y.; Oh, D. S.; Kim, J. R.; Jung, H. R.; Cho, J. Y.; Yu, K. S.; Jang. I. J. \& Shin. S. G. A variant 2677A allele of the MDR1 gene affects fexofenadine disposition. Clin. Pharmacol. Ther., 76(5):418-27, 2004.

Zanger, U. M.; Turpeinen, M.; Klein, K. \& Schwab, M. Functional pharmacogenetics/genomics of human cytochromes P450 involved in drug biotransformation. Anal. Bioanal. Chem., 392(6):1093-108, 2008.

Correspondence to:

Dr. Luis A. Salazar

Departamento de Ciencias Básicas

Facultad de Medicina, Universidad de La Frontera

Av. Francisco Salazar 01145

Casilla 54-D, Temuco

CHILE

Email: Isalazar@ufro.cl

Received: 20-08-2011

Accepted: 12-10-2011 